\section{Effects of Total Quality Management implementation on business performance in service institutions: A case of Kenya Wildlife Services}

Karani, Sharon R.

Jomo Kenyatta University of Agriculture and Technology, Nairobi, Kenya (sherryshaz2008@yahoo.com) Bichanga, Walter Okibo

Jomo Kenyatta University of Agriculture and Technology, Nairobi, Kenya (walter.okibo@yahoo.com)

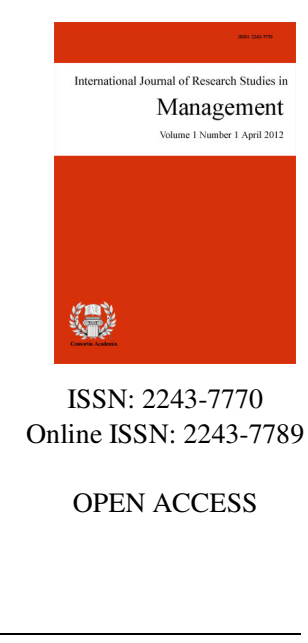

Received: 15 September 2011

Revised: 9 October 2011

Accepted: 1 November 2011

Available Online: 5 November 2011

DOI: $10.5861 /$ ijrsm.2012.v1i1.61

\title{
Abstract
}

The service sector is getting competitive every day. In order to be successful Quality Management (QM) practices ought to be the integral part of any organization's strategic management. Kenya's national parks form the pillar of the country's tourism industry. Over one million international tourists visit Kenya annually to partake in wildlife safari and other forms of nature-based tourism. However, Kenya Wildlife Services (KWS) is being faced by some challenges which they are trying to manage. These include; decline in the volume of international tourists visiting the national parks, human wildlife conflict, encroachment and poaching, and poor infrastructure. The purpose of this study is to establish how Total Quality Management (TQM) practices are employed while addressing these challenges by examining whether there are any gaps or discrepancies (positive or negative) between the service quality management offered by KWS and the actual TQM practices by (KEBS, 2008). The study was guided by the following objectives: To determine the TQM principles used, to obtain the effects of TQM implementation on organizational business performance, to determine challenges in the implementation of TQM.

Keywords: total quality management; business performance; strategic management; evaluation; quality

Acronyms: High Performance Working (HPW), Information Systems (IS), International standardization Organization (ISO), Kenya Wildlife Services (KWS), Kenya Bureau of Standards (KEBS), Organization Culture (OC), Quality Management (QM), Quality Control (QC), Total Quality Management (TQM), Total Quality Control (TQC) 


\section{Effects of Total Quality Management implementation on business performance in service institutions: A case of Kenya Wildlife Services}

\section{Introduction}

Total quality management (TQM) has become a world-wide topic in the twenty-first century. Having its roots partly in the USA and partly in Japan, it was primarily adopted by some Japanese companies in the decades immediately after World War II. With the greater successes of Japanese companies during the 1980s, companies all over the world found that it was necessary to have good quality management practices in order to stay competitive (Lagrosen, 2002). Total quality management is an enhancement to the traditional way of doing business. It is a proven technique to guarantee survival in world class competition. Only by changing the actions of management will the culture and actions of an entire organization be transformed.

Total quality management (TQM) as a management approach of an organization is centered on quality, based on the participation of all its members and aiming at long term success. This is achieved through customer satisfaction and benefits to all members of the organization and to society. In other words, TQM is a philosophy for managing an organization in a way, which enables it to meet stakeholders' needs and expectations efficiently and effectively without compromising ethical values (ISO 8402, 1994). TQM has been widely implemented throughout the world. Many firms have arrived at the conclusion that effective TQM implementation can improve their competitive abilities and provide strategic advantages in the marketplace (Anderson, Fornell, \& Lehmann, 1994). Several studies have shown that the adoption of TQM practices can allow firms to compete globally (Easton, 1993; Ernst and Young, 1991; Handfield, 1993; Hendricks \& Singhal, 1996; Womack \& Roos, 1990). Several researchers also reported that TQM implementation has led to improvements in quality, productivity, and competitiveness in only $20-30 \%$ of the firms that have implemented it (Benson, 1993). According to a survey of manufacturing firms in Georgia, the benefits of TQM are improved quality, employee participation, teamwork, working relationship, customer satisfaction, employee satisfaction, productivity, communication, profitability, and market share (Dale, Zairi, Van der Wiele, \& Williams, 2000).

A study conducted by Rategan (1992) indicated that a 90\% improvement rate in employee relations, operating procedures, customer satisfaction, and financial performance is achieved due to TQM implementation. However, Burrows (1992) reported a 95\% failure rate for initiated TQM implementation programs; Eskildson (1994), and Tornow and Wiley (1991) reported that TQM implementation has uncertain or even negative effects on performance. Longenecker and Scazzero (1993) indicated that achieving high product quality and pursuing successful TQM implementation are highly dependent on top management support. However, Motwani, Mahmoun, and Rice (1994) reported that there is no association between top management support for quality and the level of product quality achieved. Thus, conflicting research findings have been reported surrounding the effects of TQM implementation on overall business performance.

KWS is faced by some major challenges and threats which they are endeavoring to manage. They include encroachment on wildlife parks and reserves due to human population growth and poverty, volatility of international tourist visitation, conflict between people as well as human wildlife conflict, climate change, which is augmenting drought in much of our country, and floods in other areas, poor infrastructure, regional and political instability, insecurity resulting from influx of illegal weapons into the country and unfavorable resolutions reached in international conservation for a among others (Kenya Wildlife Service, 2008).

What are TQM practices really going on in Kenya service firms? The existing literature has shown that research has been done on TQM practices in Kenya higher education a case of University of Nairobi and TQM practices in Kenyan secondary schools (Ngware, 2006). No empirical research has been conducted dealing with TQM practices and their effects on overall business performance in Kenya Service firms. In order to bridge this 
gap, an investigation into the effects of TQM practices in Kenyan service institution is urgently needed. Such a study can explore the degree of the impact of TQM practices on overall business performance in firms and help in identifying problem areas and possible remedies.

\subsection{Statement of the problem}

The adoption of TQM by most organization has been hampered due to their non compliance with the procedure and principles of TQM implementation. While some organization, run TQM like a program which they expect to function and perform the magic by itself, others have used a half hearted approach to it, by using some bits and pieces of the principles. This has accounted for the failure of most organization in meeting up to their expected target from implementing this ideology (Ugboro \& Obeng, 2000). The purpose of this study was to establish how TQM practices are employed while addressing these challenges by examining whether there are any gaps or discrepancies (positive or negative) between the service quality management offered by KWS and the actual TQM practices by (Kenya Bureau of Standards, 2008). An understanding of the various TQM practices employed by KWS would aid to better the level of services quality management that KWS offers which would impact on its overall business performance.

\subsection{Research objectives}

1. To determine the TQM principles used in KWS

2. To obtain the effects of TQM implementation on organizational business performance

3. To determine challenges in the implementation of TQM practices at KWS

\subsection{Scope of the study}

The study attempted to examine the various TQM practices employed by KWS and their effects on overall business performance against the eight principles of TQM as proposed by KEBS (2008). It was conducted at KWS headquarter in Nairobi. A sample of 60 respondents selected from the different departments within the organization. Data was collected by use of questionnaire. Furthermore, there was also need to assess whether the TQM practices that have been put in place in KWS have made any significant effect on its overall business performance and if not how that can be improved. The study applied the eight principles of quality management (Kenya Bureau of Standards, 2008) to assess the extent to which TQM has been implemented at KWS and its effect on overall business performance. (Please see figure 1 for the conceptual framework of the study)

\section{Background}

This part focused on the identification of the theoretical framework, concept of TQM on the basis of literature review. It discussed the purpose of TQM, its concepts from quality gurus and other concepts, TQM principles, its effects from a number of researchers in the field of TQM, its implication in the service institutions and related literature of the major TQM Issues under this study such as: employee satisfaction, customer satisfaction, service quality, and business performance.

Quality authorities like Joseph Juran (1950s), Edward Deming (1950s), and Edward Deming (1980s) have put several approaches to improve company performance. These approaches are embodied in a set of quality management practices, known as TQM. On account of these policies different approaches have been adopted for the introduction of quality management in Service Company, such as self assessment and external assessment of the company and different models of TQM (Wiklund \& Edvardsson, 2003). The Deming's approach to TQM (1986), Juran's approach to TQM (1994), Crosby's approach to TQM (1979), Feigenbaum's approach to TQM (1991), Ishikawa's approach to TQM (1985), and results from quality gurus were well reviewed. 


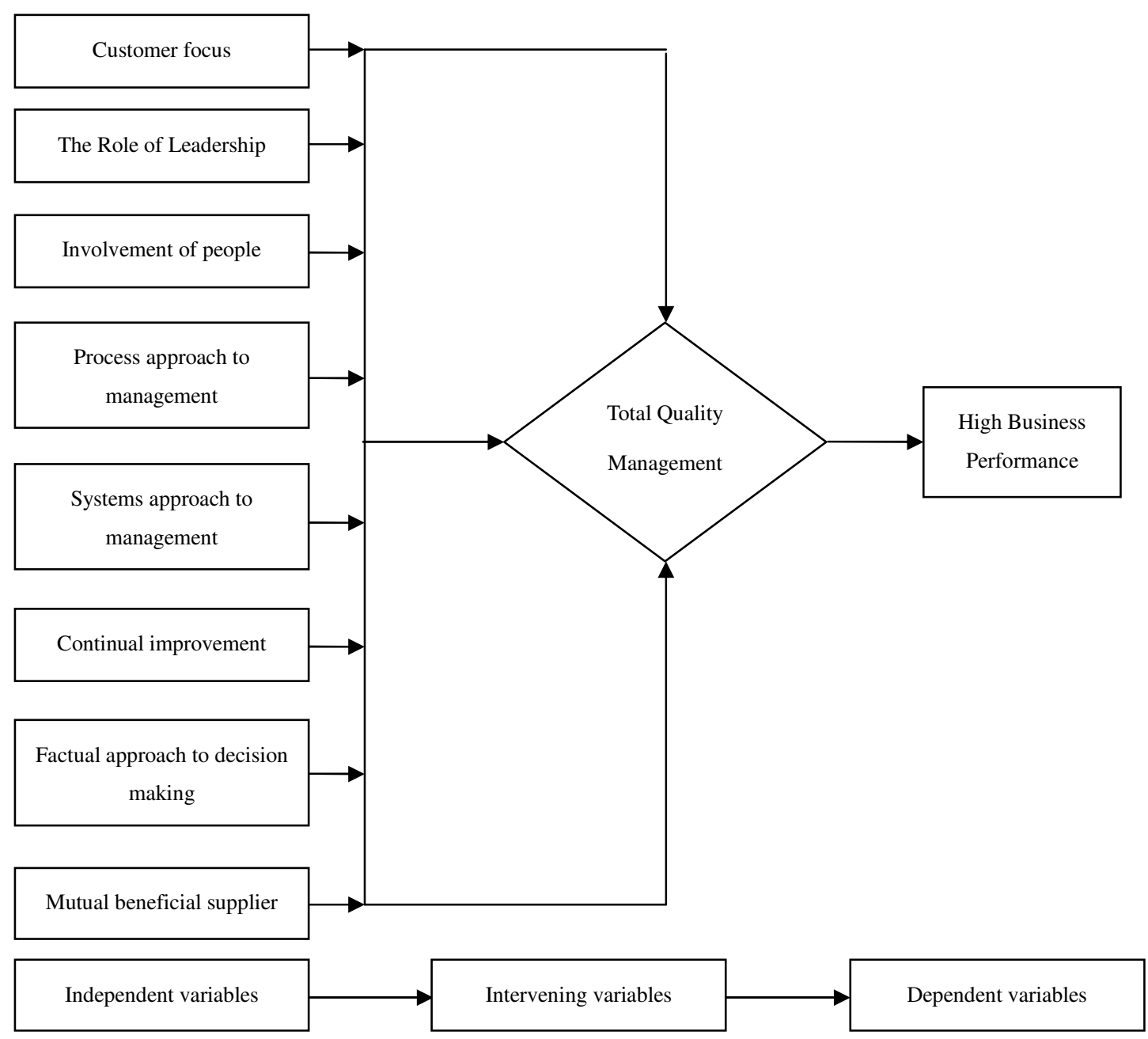

Figure 1. Conceptual framework of the study

\subsection{Knowledge gap}

The existing literature has showed that research has been done on TQM practices in Kenya higher education, Factors Affecting TQM Processes in State Corporation for Customer Satisfaction, and TQM practices in Kenyan secondary schools. Little or no empirical research has been conducted dealing with TQM practices and their effects on overall business performance in Kenya Service firms. In order to bridge this gap, an investigation into the effects of TQM practices in Kenyan service institution is needed.

\section{Methodology}

The research adopted a descriptive case study research design. The design is preferred for it is fact finding and exploratory in the capacity of establishing the truth. Quantitative technique was used since the expected information from the field involved factual elements that would be presented using descriptive statistics. The target population of this study comprised of both KWS top management, middle and junior from the different departments based at the KWS head quarters - Nairobi, which comprises of 600 individuals. Simple random technique was used to select the research size since KWS has a large number of employees. A sample size of 60 ( $10 \%$ of the target population) was selected from the target population.

The research instrument used was questionnaire. The field survey was conducted in KWS head quarter. A total of 60 structured questionnaires were distributed to the various departments at KWS. Information on TQM implementation on business performance was obtained by the use of 28 statements of TQM set of practices on 
the structured questionnaire based on KEBS proposed TQM principles. Additional attributes such as "effects of TQM on business performance" and "challenges facing TQM implementation" were also included in the questionnaire. The secondary data for this study was gathered from existing published works i.e. current TQM Journals and books, Jomo Kenyatta University of Agriculture and Technology (JKUAT) library, KWS Strategic Plan, KWS Annual Report and ISO Implementation handbooks. The secondary data were however not used in the analysis but was used in the introduction and literature review sections of the study.

The questionnaires were checked for completeness and consistency of information at the end of every field data collection day and before storage. Analysis was done using statistical package for social science (SPSS). The data was tabulated by making logical interpretation, conclusion and recommendation. Descriptive statistics (i.e. frequency analysis) were computed for presenting and analyzing the data. A summary sheet was used to tally responses from participants before analysis. Proper fields or units (categories or themes of data) created to describe all variables in the study, by use of descriptive statistics. Data was presented in the form of frequency distribution tables, graphs and pie charts that facilitated description and explanation of the study findings.

\section{Results and discussions}

In the study, a total of 60 questionnaires were issued of which 54 were successfully filled, returned and taken as valid samples.

Table 1

Response rate

\begin{tabular}{ccc}
\hline Questionnaires issued & Returned & $\%$ return rate \\
\hline 60 & 54 & $90 \%$ \\
\hline
\end{tabular}

According to Mugenda and Mugenda (1999) a 50\% response rate is adequate, $60 \%$ good and above $70 \%$ rated very good. This implies that basing on this assertion; the response rate in this case of $90 \%$ is very good.

\subsection{Reliability analysis}

For reliability analysis Cronbach's alpha was calculated by application of SPSS. The value of the alpha coefficient ranges from 0 to 1 and may be used to describe the reliability of factors extracted from dichotomous (that is, questions with two possible answers) and/or multi-point formatted questionnaires or scales (i.e., rating scale: 1 = poor, 5 = excellent). A higher value shows a more reliable generated scale. Nunnally (1970) has indicated 0.7 to be an acceptable reliability coefficient. As the alpha coefficients were all greater than 0.7 , a conclusion was drawn that the instruments had an acceptable reliability coefficient and were appropriated for the study.

Table 2

Reliability analysis

\begin{tabular}{lcc}
\hline \multicolumn{1}{c}{ Items } & Cronbach alpha & Number of items \\
\hline Role of leadership in TQM Implementation & 0.7141 & 5 \\
Focus of TQM Implementation on customer satisfaction & 0.845 & 5 \\
Staff Involvement in TQM Implementation & 0.921 & 16 \\
Process approach to TQM Implementation & 0.768 & 10 \\
Continual Improvement in implementation of TQM & 0.721 & 12 \\
Factual decision making & 0.813 & 5 \\
\hline
\end{tabular}



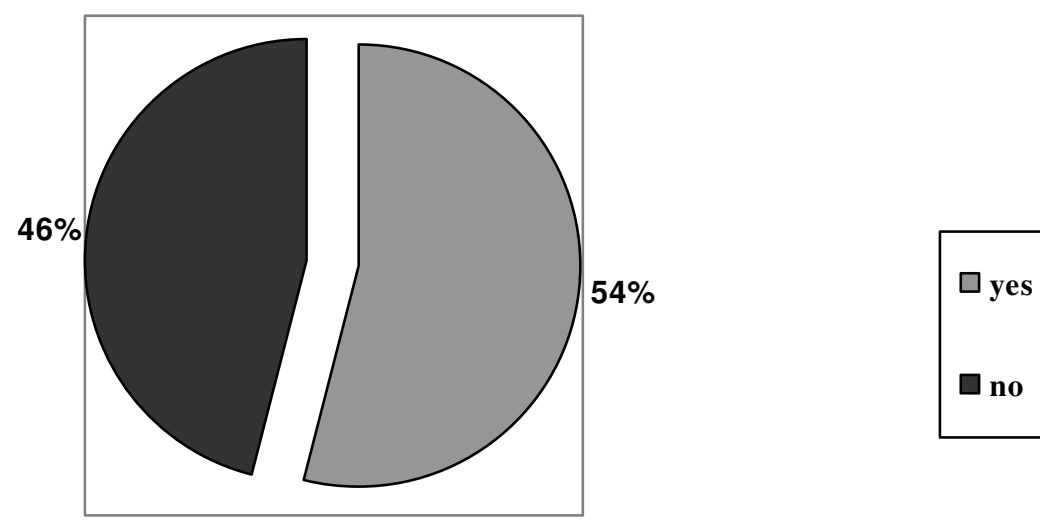

Figure 2. Effect of organization culture

Majority of the respondents agreed that organization culture (working conditions) affects its TQM implementation positively. This implies that KWS have a quite conducive working environment that affects TQM implementation positively, these included sentiments such as fairness in applying policies, training and development, top management commitment, and team work within the organization.

\subsection{Descriptive analysis}

Total Quality Management principles used at KWS are as such:

\section{Table 3}

The role of leadership in TQM in implementation

\begin{tabular}{lccccc}
\hline \multicolumn{1}{c}{ Items } & $\begin{array}{c}\text { Very } \\
\text { Dissatisfied }\end{array}$ & Dissatisfied & $\begin{array}{c}\text { A little bit } \\
\text { satisfied }\end{array}$ & Satisfied & $\begin{array}{c}\text { Very } \\
\text { satisfied }\end{array}$ \\
\hline $\begin{array}{l}\text { Provision of quality service to its } \\
\text { stakeholders }\end{array}$ & $7.4 \%$ & $0 \%$ & $66.7 \%$ & $25.9 \%$ & $0 \%$ \\
Creating and sustaining, clear visions, & $0 \%$ & $0 \%$ & $46.3 \%$ & $35.2 \%$ & $18.5 \%$ \\
goals, targets and shared values & 0 & 0 & 25 & 19 & 10 \\
$\begin{array}{l}\text { Providing staff with required } \\
\text { resource, training and development }\end{array}$ & $5.6 \%$ & $13.0 \%$ & $40.7 \%$ & $40.7 \%$ & $0 \%$ \\
Inspiring, empowerment and & 3 & 7 & 22 & 22 & 0 \\
recognizing staff contribution & $11.1 \%$ & $7.4 \%$ & $29.6 \%$ & $51.9 \%$ & $0 \%$ \\
$\begin{array}{l}\text { Encourage team work and } \\
\text { performance appraisal }\end{array}$ & 6 & 4 & 16 & 28 & 0 \\
\hline
\end{tabular}

Note. Responses were based on a scale of: 1 = Very dissatisfied, $2=$ Dissatisfied, $3=$ A little bit Satisfied $4=$ satisfied, $5=$ Very satisfied. The values indicate the number of respondents and the percentage indicate the percentile representative of the total respondents.

As reflected from the findings $61.1 \%$ of the respondents were a little bit satisfied in the top management encouraging team work and performance appraisal this was supported further by $38.9 \%$ being satisfied. The implication of these findings is that Top management is very much committed in the implementation of TQM 
Effects of Total Quality Management implementation on business performance in service institutions

through providing staff with resources, inspiring, empowering, and recognition of employees. However top management should put emphasize on teamwork and performance appraisal, creation and sustaining clear visions, goals and target and provision of quality services since respondents were a little bit satisfied.

Table 4

Customer focus in TQM implementation

\begin{tabular}{|c|c|c|c|c|c|}
\hline Items & Not at all & less extent & $\begin{array}{c}\text { Moderate } \\
\text { extent }\end{array}$ & $\begin{array}{c}\text { large } \\
\text { extent }\end{array}$ & $\begin{array}{c}\text { Very great } \\
\text { extent }\end{array}$ \\
\hline Organization establishes and understand & $0 \%$ & $7.41 \%$ & $25.93 \%$ & $66.67 \%$ & $0 \%$ \\
\hline current and future customer needs & 0 & 4 & 14 & 36 & 0 \\
\hline Organization ensures that it & $0 \%$ & $5.56 \%$ & $33.33 \%$ & $61.11 \%$ & $0 \%$ \\
\hline $\begin{array}{l}\text { communicates and balances the needs } \\
\text { and expectations of all interested parties }\end{array}$ & 0 & 3 & 18 & 33 & 0 \\
\hline Management measure customer & $0 \%$ & $7.41 \%$ & $46.3 \%$ & $31.48 \%$ & $14.81 \%$ \\
\hline $\begin{array}{l}\text { satisfaction and rectifies where } \\
\text { necessary }\end{array}$ & 0 & 4 & 25 & 17 & 8 \\
\hline Management responses to customers' & $13.00 \%$ & $53.7 \%$ & $13.00 \%$ & $20.37 \%$ & $0 \%$ \\
\hline complaints & 7 & 29 & 7 & 11 & 0 \\
\hline Are you satisfied with the level of & $5.55 \%$ & $0 \%$ & $55.56 \%$ & $38.89 \%$ & $0 \%$ \\
\hline service delivery to customer & 3 & 0 & 30 & 21 & 0 \\
\hline
\end{tabular}

Note. The above responses were based on a scale of: $1=$ Not at all, $2=$ Less extent, $3=$ Moderate extent, $4=$ Large extent, $5=$ Very great extent. The values indicate the number of respondents and the percentage indicate the percentile representative of the total respondents.

The findings implies that KWS are customer oriented and that it practices TQM to a very large extent, this is seen through a representation of $66.67 \%$ of respondents agreed that KWS establishes and understands current and future customer needs, a $61.11 \%$ representation of respondents agreed that the organization communicates and balances the needs and expectations of all interested parties to a very large extent. However the issue of customer complaints should be addressed since a huge percentage of respondent reflected by $53.7 \%$ agree that management respond to customer complaints to a less extent.

\section{Table 5}

Staff involvement in TQM Implementation

\begin{tabular}{|c|c|c|c|c|c|c|}
\hline Items & Not at all & less extent & $\begin{array}{c}\text { Moderate } \\
\text { extent }\end{array}$ & $\begin{array}{l}\text { large } \\
\text { extent }\end{array}$ & $\begin{array}{c}\text { Very great } \\
\text { extent }\end{array}$ & Total \\
\hline To what extent does management empower & $0 \%$ & $0 \%$ & $35.19 \%$ & $64.81 \%$ & $0 \%$ & $100 \%$ \\
\hline employee and encourage innovation? & 0 & 0 & 19 & 35 & 0 & 54 \\
\hline To what extent does staff establish quality & $0 \%$ & $20.4 \%$ & $33.33 \%$ & $46.3 \%$ & $0 \%$ & $100 \%$ \\
\hline $\begin{array}{l}\text { improvement teams, corrective action teams } \\
\text { and suggestion schemes? }\end{array}$ & 0 & 11 & 18 & 25 & 0 & 54 \\
\hline To what extent do the employee participates in & $0 \%$ & $0 \%$ & $20.37 \%$ & $48.15 \%$ & $29.63 \%$ & $98.1 \%$ \\
\hline organization decision making? & 0 & 0 & 11 & 26 & 16 & 53 \\
\hline
\end{tabular}

Note. The responses were based on a scale of: $1=$ Not at all, $2=$ Less extent, $3=$ Moderate extent, $4=$ Large extent, $5=$ Very great extent. The values indicate the number of respondents and the percentage indicate the percentile representative of the total respondents. 
Karani, S. R. \& Bichanga, W. O.

Majority of the staff are represented by 64.81 percent, this reveals that KWS management empower and encourage employee innovation to a very large extent, and only 3.19 to a moderate extent. KWS staff are involved in TQM processes to a very large extent represented by a 48.15 percent, 29.63 is to a very great extent and 20.37 to a moderate extent. This clearly shows the role of leadership in employee participation in TQM implementation is well represented at KWS.

\section{Table 6}

Employees' motivation process

\begin{tabular}{llcc}
\hline \multicolumn{1}{c}{ Items } & Response & Frequency & Percentage \\
\hline Training & Yes & 47 & 87.04 \\
& No & 7 & 12.96 \\
& Total & $\mathbf{5 4}$ & $\mathbf{1 0 0}$ \\
Product or service quality initiatives & Yes & 14 & 25.93 \\
& No & 40 & 74.07 \\
& Total & $\mathbf{5 4}$ & $\mathbf{1 0 0}$ \\
Initiative to increase customer service & Yes & 11 & 20.37 \\
& No & 43 & 79.63 \\
& Total & $\mathbf{5 4}$ & $\mathbf{1 0 0}$ \\
Company drive for referrals & Yes & 4 & 7.407 \\
& No & 50 & 92.59 \\
Employee appreciation & Total & $\mathbf{5 4}$ & $\mathbf{1 0 0}$ \\
& Yes & 40 & 74.07 \\
& No & 14 & 25.93 \\
Special employee of the year & Total & $\mathbf{5 4}$ & $\mathbf{1 0 0}$ \\
(recognition) & Yes & 13 & 24.07 \\
& No & 41 & 75.93 \\
& Total & $\mathbf{5 4}$ & $\mathbf{1 0 0}$ \\
\hline
\end{tabular}

Around $74.07 \%$ of the respondent agreed that KWS practice appreciation as a motivation process to its employees thus it can be argued that KWS do motivate its staff through various processes such as employee appreciation and training. Management should emphasize on the other motivation process such as employee recognition, company drive for referrals, initiatives to increase customer services and product or service quality initiatives as employee motivation processes.

\subsection{Factual approach to decision making}

A variety of employees should be involved in the development of the vision statement and quality policy, which in return, should be well communicated to employees at different levels to stimulate commitment. Majority of the respondent represented by a 50 percent agree that KWS uses factual approach to decision making to a moderate extent, 42.62 percent to a large extent and 7.4 percent to a less extent. This implies that KWS practices TQM based on the decision making factual approach. 


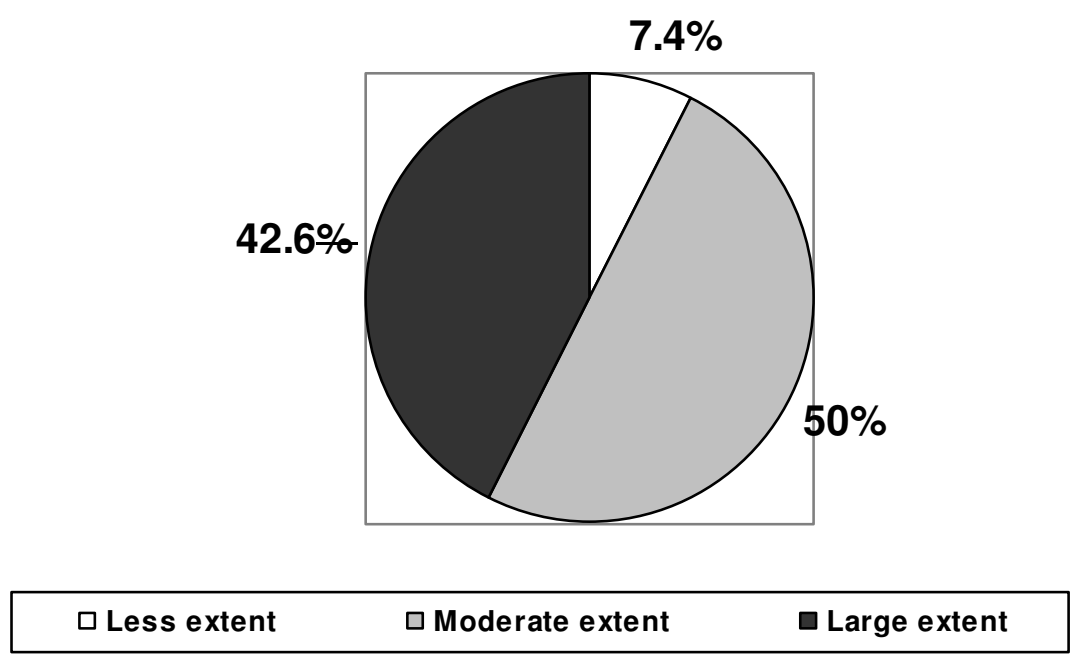

Figure 3. Factual decision making

\subsection{Mutual benefits supplier}

Developing partnerships with suppliers is one of the major TQM implementation practices. External cooperation between a firm and its suppliers has merits in the just-in time purchasing systems. Working collaboratively with suppliers on a long-term basis is truly beneficial. The below table indicate the basis in which KWS selects its suppliers.

\section{Table 7}

Mutual benefits supplier

\begin{tabular}{llcc}
\hline \multicolumn{1}{c}{ Statement } & Response & Frequency & Percentage \\
\hline Price basis & Yes & 33 & 61.11 \\
& No & 21 & 38.89 \\
& Total & $\mathbf{5 4}$ & $\mathbf{1 0 0}$ \\
Recognition basis & Yes & 7 & 12.96 \\
& No & 47 & 87.04 \\
Quality basis & Total & $\mathbf{1 0 0}$ \\
& Yes & $\mathbf{5 4}$ & 79.63 \\
& No & 43 & 20.37 \\
\hline
\end{tabular}

For TQM to be effective it is apparent that firms select their suppliers on the basis of quality, rather than solely on price, since price has no meaning without a measure of the quality being purchased. The findings reveal that KWS practices TQM on supplier quality management to a great extent as required by the quality management systems, whereby supplier should be selected based on quality rather than price. Furthermore, the finding implies that the organization has made use of process approach to a moderate extent; hence the organization needs to come up with strategies to improve on its process approach to TQM. 


\section{Table 8}

Process approach to TQM

\begin{tabular}{lcc}
\hline \multicolumn{1}{c}{ Items } & Mean & $S D$ \\
\hline $\begin{array}{l}\text { Does the organization process approach systematically define the } \\
\text { activities necessary to achieve/obtain desired results? }\end{array}$ & 3.3 & 0.57 \\
$\begin{array}{l}\text { Evaluating risks, consequences and impacts of activities on customers, } \\
\text { suppliers and other stakeholders }\end{array}$ & 3.31 & 0.47 \\
Analyzing and measuring capabilities of key activities & 3.26 & 0.44 \\
\hline
\end{tabular}

Note. The responses were based on a scale of: $1=$ not at all, $2=$ less extent, $3=$ moderate extent $4=$ large extent, $5=$ very great extent.

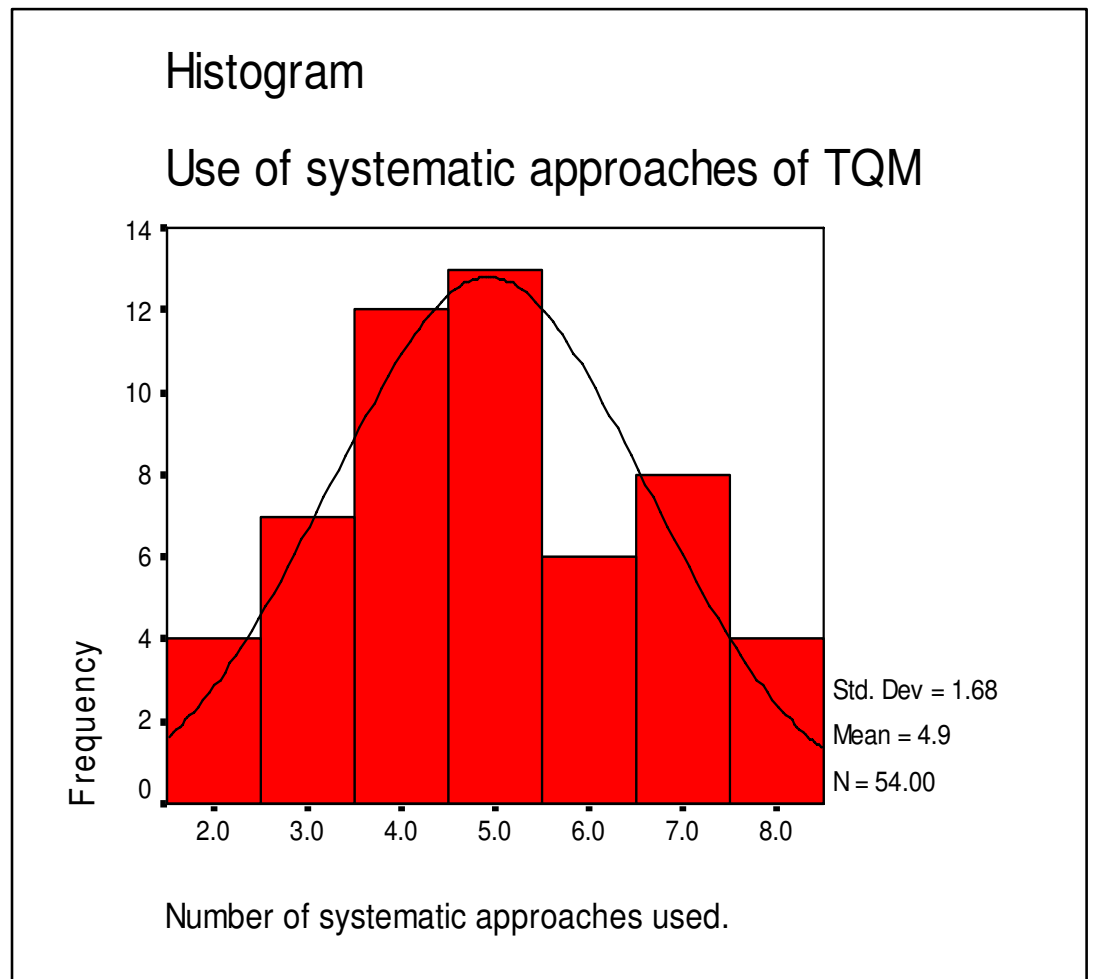

Figure 4. Use of systems approach to TQM Implementation

The mean which is 4.9 implies that on average 5 of the 10 systems approach tools are used by KWS in TQM implementation. This implies that the systems approach is one of the principles used by KWS in implementation of TQM.

According to the next table $94 \%$ of the respondents accepts that balancing score cards are used by the organization while $79.62 \%, 79.62 \%, 64.81 \%$ and $57.4 \%$ of the respondents accept that benchmarking, Quality manuals, employee reviews and standardized audits respectively have also been put in place by the organization for implementation of TQM. This implies that KWS have made use of the TQM tools and technique to a very large extent. Furthermore, the histogram is skewed to the right which showing that according to most of the employees 5 of the 10 practices is used. The mean which is 4.4 implies that on average 5 of the 10 continual improvement practices are used by KWS in TQM implementation. This implies that continual improvement principle is one of the practices used by KWS in implementation of TQM. 
Table 9

Systems approach to TQM implementation

\begin{tabular}{lcc}
\hline \multicolumn{1}{c}{ Tools/Techniques } & Frequency & Percentage \\
\hline Balancing Score cards & & \\
Yes & 51 & 94.44 \\
No & 3 & 5.56 \\
Total & $\mathbf{5 4}$ & $\mathbf{1 0 0}$ \\
Benchmarking & & \\
Yes & 43 & 79.63 \\
No & 11 & 20.37 \\
Total & $\mathbf{5 4}$ & $\mathbf{1 0 0}$ \\
Quality Manuals & & \\
Yes & 43 & 79.63 \\
No & 11 & 20.37 \\
Total & $\mathbf{5 4}$ & $\mathbf{1 0 0}$ \\
Employee performance review & & $\mathbf{6 4 . 8 1}$ \\
Yes & 35 & 35.19 \\
No & 19 & $\mathbf{1 0 0}$ \\
Total & $\mathbf{5 4}$ & $\mathbf{5 7 . 4 1}$ \\
Standardized Audits & & 42.59 \\
Yes & 31 & $\mathbf{1 0 0}$ \\
No & 23 & $\mathbf{5 4}$ \\
Total & & \\
\hline
\end{tabular}

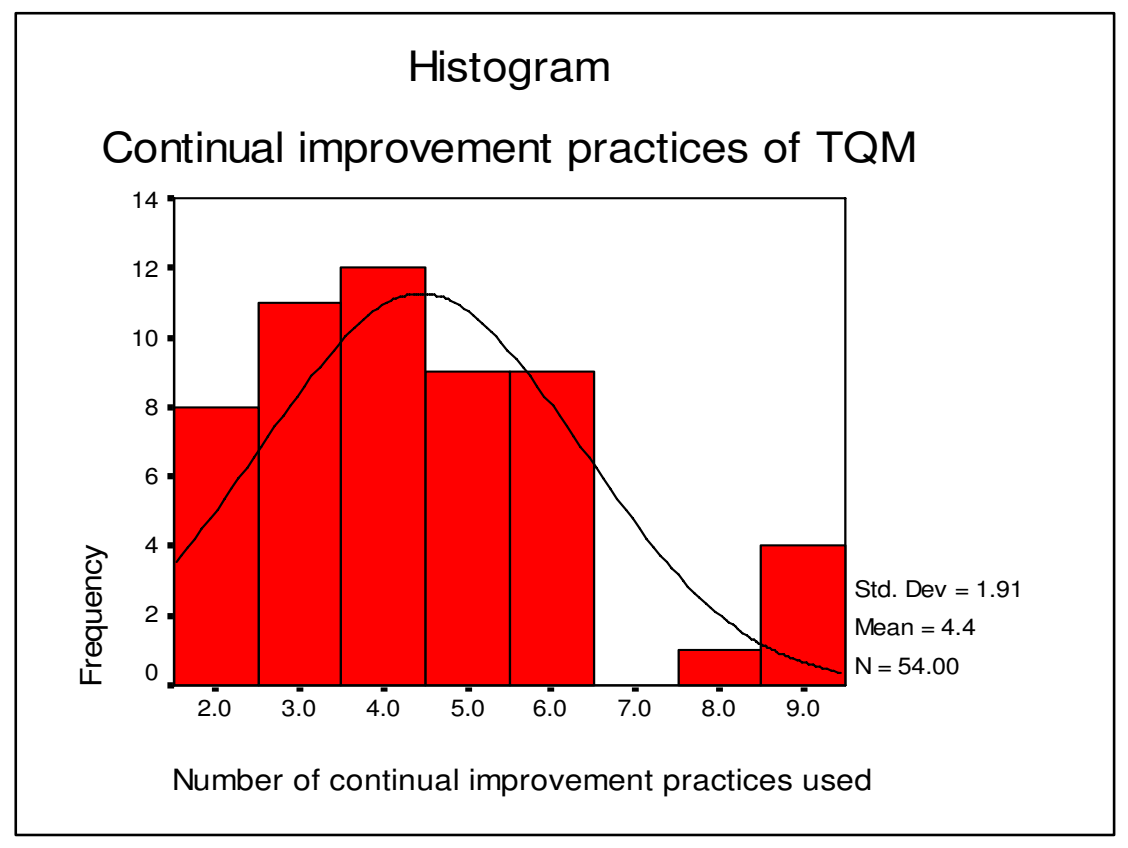

Figure 5.Continual improvement in implementation of TQM 
Karani, S. R. \& Bichanga, W. O.

Table 10

Continual improvement in implementation of TQM

\begin{tabular}{lcc}
\hline \multicolumn{1}{c}{ Tools/Techniques } & Frequency & Percentage \\
\hline Continual Improvement policies & & \\
$\quad$ Yes & 40 & 74.07 \\
No & 14 & 25.93 \\
$\quad$ Total & $\mathbf{5 4}$ & $\mathbf{1 0 0}$ \\
Performance appraisal schemes & & \\
$\quad$ Yes & 33 & 61.11 \\
No & 21 & 38.89 \\
Total & $\mathbf{5 4}$ & $\mathbf{1 0 0}$ \\
Research team for innovative solutions & & \\
Yes & 33 & 61.11 \\
No & 21 & 38.89 \\
Total & $\mathbf{5 4}$ & $\mathbf{1 0 0}$ \\
Improvement programs & & \\
Yes & 29 & 53.70 \\
No & 25 & 46.30 \\
Total & $\mathbf{5 4}$ & $\mathbf{1 0 0}$ \\
\hline
\end{tabular}

Around $74 \%$ of the respondents accepts that continual improvement policies are used by the organization while $74.07 \%, 61.11 \%, 61.11 \%$ and $53.70 \%$ of the respondents accept that Continual improvement policies, Performance appraisal schemes, research team for innovative solution, and improvement programs respectively have also been put in place by the organization for implementation of TQM. This implies that continual improvement principle is one of the practices used by KWS in implementation of TQM.

Table 11

Focus of TQM implementation on customer satisfaction

\begin{tabular}{lcc}
\hline \multicolumn{1}{c}{ Items } & Mean & $S D$ \\
\hline $\begin{array}{l}\text { Organization establishes and understands current and future customer needs } \\
\text { Organization ensures that it communicates and balances the needs and expectations }\end{array}$ & 3.59 & 0.63 \\
of all interest parties i.e. customers, owners, employees, suppliers, financier and local \\
community. & 3.56 & 0.60 \\
Management measures customer satisfaction and rectifies where necessary & 3.53 & 0.84 \\
Management response to customers' complaints. & 3.28 & 1.19 \\
Are you satisfied with the level of service delivery to customer? & 3.28 & 0.74 \\
\hline
\end{tabular}

Note. The responses were based on a scale of: $1=$ Not at all, $2=$ less extent, $3=$ moderate extent $4=$ Large extent, $5=$ Very great extent.

The results in table indicate that according to the respondents the management establishes and understands current and future customer needs to a moderate extent as shown by (mean $=>3$ ). The results also reveals that to a moderate extent the organisation; ensures that it communicates and balances the needs and expectations of all interest parties i.e. customers, owners, employees, suppliers, financier and local community, measures customer 
Effects of Total Quality Management implementation on business performance in service institutions

satisfaction and rectifies where necessary and responds to customers' complaints as shown by (mean=>3). By the (mean>=3) it also implies that respondents are also to moderate extent satisfied by the service delivery to customers. This shows that the organisation's TQM practices its focus on customer satisfaction to a moderate extent and that effort should be put to ensure customer satisfaction.

\section{Table 12}

Organization's business performance and TQM implementation

\begin{tabular}{lcc}
\multicolumn{1}{c}{ Items } & Mean & $S D$ \\
\hline Service quality & 2.98 & 1.07 \\
Strategic Business performance & 2.96 & 1.03 \\
Employees satisfaction & 3.11 & 1.17 \\
\hline
\end{tabular}

Note. The responses on public perception were based on a scale of: $1=$ poor, $2=$ average, $3=$ Good $4=$ Very good.

The table also shows that an adequate number of respondents agree that KWS offers quality service. This is shown by the (mean $>=2.98$ ) in the scale; $1=$ Very high, $2=$ High, $3=$ Average, $4=$ low, $5=$ Very low. This implies that TQM positively affects business performance on the basis of quality of service, strategic business performance, customer satisfaction and employee satisfaction.

\section{Table 13}

Challenges affecting TQM implementation

\begin{tabular}{lcc}
\hline \multicolumn{1}{c}{ Challenges } & Frequency & Percentage \\
\hline resistant to change & 3 & 5.56 \\
application of various quality concepts & 5 & 9.26 \\
low capacity among personnel & 1 & 1.85 \\
low understanding of TQM by other staff & 5 & 9.26 \\
cascading the program to the bottom of the pyramid & 10 & 18.5 \\
lack of funds & 6 & 11.1 \\
lack of adequate information & 3 & 5.56 \\
internal threat & 5 & 9.26 \\
dealing with negative attitude toward the program from staff & 7 & 13 \\
Lack of resource & 3 & 5.56 \\
lack of commitment & 2 & 3.7 \\
frequent transfers unpredictable transfer of personnel & 2 & 3.7 \\
unwillingness from some of the management & 2 & 3.7 \\
Total & 2 & $\mathbf{1 0 0}$ \\
\hline
\end{tabular}

The above finding implies that the major challenge in TQM implementation is cascading the program to the bottom of the pyramid. This is a challenge that many organizations are facing when implementing TQM, most organization use bits and pieces of the TQM principles more especially organization use TQM principles that 
Karani, S. R. \& Bichanga, W. O.

support their existing organization culture thus leading to ineffective TQM implementation. Efforts should be done to mitigate the above challenges for successful implementation of TQM.

\subsection{Correlation analysis}

\section{Table 14}

Correlation matrix

\begin{tabular}{lccc}
\hline \multicolumn{1}{c}{ Items } & Value & $\begin{array}{c}\text { Organizational } \\
\text { performance }\end{array}$ & TQM implementation \\
\hline \multirow{2}{*}{ Organizational performance } & Pearson Correlation Sig. & 1 & 0.87 \\
TQM implementation & Pearson Correlation Sig. & 0.87 & 0.000 \\
& & 0.000 & 1 \\
\hline
\end{tabular}

The table above indicates that the organization's performance is highly correlated with TQM implementation. This is shown by the significant correlation coefficient of 0.87 . This implies that proper TQM implementation results in proper organizational performance.

\subsection{Regression analysis}

\section{Table 15}

Model Summary

\begin{tabular}{cccc}
\hline$R$ & $R$ Square & Adjusted $R$ Square & Std. Error of the Estimate \\
\hline 0.86667 & 0.75111 & 0.74633 & 0.096 \\
\hline
\end{tabular}

The model summary in table 15 above shows a strong relationship with $\mathrm{R}=0.867$ and $\mathrm{R}^{2}=0.75$ this implies that $75 \%$ of the corresponding change in the organizations performance is explained by TQM implementation.

\section{Table 16}

Regression Coefficients

\begin{tabular}{lccc}
\hline \multicolumn{1}{c}{ Items } & Coefficients & T value & Sig. \\
& $B$ & Std. Error & -1.56 \\
(Constant) & -0.09 & 0.06 & 12.5272 \\
\hline
\end{tabular}

A test on the beta coefficient of the resulting model, indicated that the coefficient $\beta=1.11$ is significantly greater than $0, p=0.0$ which is less than $\mathrm{p}=0.05$. The constant is however not significantly greater than 0 since it has a $\mathrm{p}$ value $\mathrm{p}=0.12$ which is greater than 0.05 .

The model thus holds as;

Organizations' performance $=\beta$ (TQM implementation $)$ where $\beta>0$. 
A test for the normality assumption of the least square estimation used for regression was done by a histogram of standardized residuals as in figure 6 below.

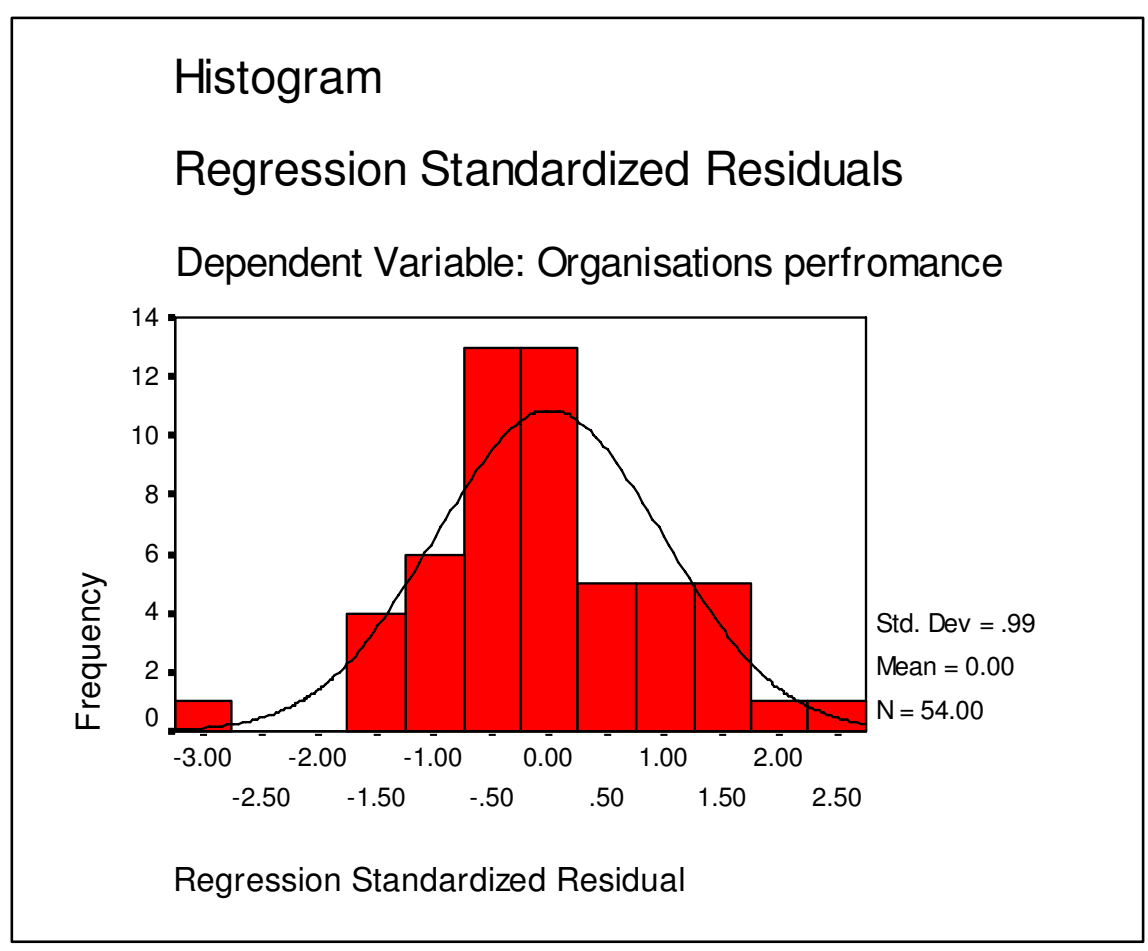

Figure 6. Regression standardized residuals

Distribution with a mean of 0 and standard deviation of 1 ; the normality assumption of the residuals is thus met implying that the model above is appropriate.

\section{Conclusion and recommendation}

In connection to the role of leadership in TQM implementation, the finding of this study, results revealed that the role of leadership has a positive impact on TQM implementation. The finding also reveals that KWS practice TQM to a great extent since managerial decisions directly affects the implementation processes. Customer focus was found to be a driving factor that influences the need to adopt TQM this cannot be achieved without the participation of the entire employees. The findings on customer focus in TQM implementation implies that KWS are customer oriented and that it practices TQM to a very large extent. From the finding, it is revealed that employee involvement in the implementation of TQM is a major factor that most firms should put in to consideration since they are the determinants for failure or success of an organization. The findings also revealed that KWS practice five TQM tools to a great extent. This implies that KWS has made use of quality tools to a great extent. The study finding revealed that KWS practices continual improvement through continual improvement policy, performance appraisal schemes, and research schemes for innovative solution and improvement programs. This clearly shows that continual improvement is highly being practiced in the organization.

Majority of the respondents agree that KWS practices process approach to a moderate extent with a mean representation of 3. It evaluates risks, consequences and impacts of activities on customers and other stakeholder to a moderate extent, it also analyze and measures capabilities of key activities to a moderate extent. This implies that KWS has made use of process approach to a moderate extent and that efforts should be made to ensure there 
is proper linking of the organizational strategies and approaches to quality management for effective process approach to TQM. From the findings, KWS selects its suppliers based on quality, thus it can be concluded that KWS practices supplier quality management as required by quality management system. The study findings revealed that TQM on customer satisfaction is practiced to a moderate extent with a mean representation of 3 . KWS establishes and understand current and future customer needs to a moderate extent, it also balance the needs and expectations of all interested parties to a moderate extent, measures customer satisfaction and rectifies where necessary to a moderate extent and respond to customer complains to a moderate extent. This implies that KWS needs to put more effort to ensure customer satisfaction since customers are the determinants of success or failure of a business.

The research findings imply that the major challenge in TQM implementation is cascading the program to the bottom of the pyramid. Management should ensure TQM awareness to all staff levels. Most organization use bits and pieces of the TQM principles more especially organization use TQM principles that support their existing organization culture thus leading to ineffective TQM implementation. Efforts should be done to mitigate the above challenges for successful implementation of TQM.

\subsection{Conclusions}

Strategic management in any organization is a crucial factor in efficient and effective leadership for successful functioning of any organization. The study finding concludes that effective management leads to improved performance, there is need to put more emphasis on all TQM principle to ensure more organization business performance, tools in process approach need to be fully employed in implementation of TQM. There is also need to focus more on already established factors like management response to customer' complaints, service delivery to customers and organization communication and balancing the needs and expectation of interested parties which have an impact on customer satisfaction. Most employees maintain that the organization should understand the current and future needs of customers; they also agree that business performance and customer satisfaction are enhanced by quality management practices. The study findings also infer that use of process approach in defining the activities necessary to achieve desired results, evaluating risks, consequences and impacts of activities on customers, suppliers and other stockholders and analyzing and measuring of the capabilities of key activities can also have a major impact on organization business performance.

\subsection{Recommendations}

The study recommends that emphasis should be put on the incorporation of all the principles of TQM for successful implementation of TQM and for the success of the organization. The role of leadership, employee participation, customer focus, supplier quality management, continual improvement, and organizational culture are apparent for the success of the firm in terms of market share, productivity, profitability and overall business performance. TQM implementation has positive effects on overall business performance. Implementing TQM does pay off since the benefits accrued include; improved quality, employee satisfaction, productivity, employee participation, teamwork, communication, profitability and market share. The study recommends that firm should establish their quality management systems according to the requirement of ISO 9000 effectively for effective TQM implementation and for the success of the firm. Flexibility of the organizational culture will determine the success or failure of implementing TQM. Resistance to change, lack of commitment, cascading the program to the bottom of the pyramid are some of the challenges faced in TQM implementation. The study recommends that firms should be flexible enough when implementing TQM and management should develop a quality culture by changing perception and attitudes towards quality. Organization inflexibility and inertia has provided an environment that weakened and erodes the foundation of TQM.

\section{Definition of terms}

- Continuous improvement - is defined as the relentless pursuit of improvement in the delivery of value 
Effects of Total Quality Management implementation on business performance in service institutions

to customers (Turney \& Anderson, 1989).

- Customer focus - can be defined as the degree to which a firm continuously satisfies customer needs and expectations. A successful firm recognizes the need to put the customer first in every decision made (Philips, 1995).

- Employee participation - and involvement is the process of empowering the members of the organization to make decisions and to solve problems appropriate to their levels in the organization (Sangeeta \& Banwe, 2004).

- Supplier quality management - can be defined as the set of supplier related quality management practices for improving suppliers' quality of products and services. This is exemplified by firm-supplier partnership, product quality as the criterion for supplier selection, participation in suppliers, communication with suppliers, understanding of supplier performance, and supplier quality audit (Mann, 1992; Zhang, 2000).

- Total Quality Management - is a philosophy for managing an organization in a way which enables it to meet stakeholders' needs and expectations efficiently and effectively without compromising ethical values (ISO 8402, 1994).

Acknowledgment: We wish to express our gratitude to our beloved families for not just offering very incisive comments but also for their great patience with us on this research. Dr. Bichanga's family: Percy Nduta Okibo, Ethan Nyameta and Ella Nyasuguta; Ms. Karani's family; Sam, Hansel and Caroline. Thank you so much for allowing us to appraise ourselves. Special thanks to KWS strategy and change staff for giving us relevant materials related to this study.

\section{References:}

Anderson, E. W., Fornell, C., \& Lehmann, D. R. (1994). Customer satisfaction, market share, and profitability: Findings from Sweden. Journal of Marketing, 5, 53-56. doi: 10.2307/1252310 $<$ http://dx.doi.org/10.2307/1252310>

Benson, T. (1993). TQM: A child takes a first few faltering steps. Industry Week, 242(7), 17.

Burrows, P. (1992). TQM reality check: It works, but it's not cheap or easy. Electronic Business, 18, 8-22.

Crosby, P. B. (1979). Quality is free. New York: McGraw-Hill, Inc.

Dale, B. D., Zairi, M., Van der Wiele, A., \& Williams, A. R. T. (2000). Quality is dead in Europe: Long live experience - true of false? Measuring Business Excellence, 4(3), 4-11. doi: $10.1108 / 13683040010377737$ <http://dx.doi.org/10.1108/13683040010377737>

Deming, W. E. (1986). Out of crisis. Cambridge, MA: Massachusetts Institute of Technology, Center for Advanced Engineering Study.

Easton, G. (1993). The 1993 state of US Total Quality Management: A Baldrige examiner's perspective. California Management Review, 35(3), 32-54.

Ernst and Young. (1991). American quality foundation, international quality study: The definitive study of the best international quality management practices. Cleveland, $\mathrm{OH}$ : Ernst \& Young.

Eskildson, L. (1994). Improving the odds of TQM's success. Quality Progress, 27(4), 61-63.

Feigenbaum, A. V. (1991). Total quality control (3rd ed.). New York: McGraw-Hill, Inc.

Handfield, R. B. (1993). A resource dependence view of just-in-time purchasing. Journal of Operations Management, 11, 289-311. doi: 10.1016/0272-6963(93)90005-A $<$ http://dx.doi.org/10.1016/0272-6963(93)90005-A>

Hendricks, K. B., \& Singhal, V. R. (1996). Quality awards and the market value of the firm: An empirical investigation. Management Science, 42(3), 415-436. doi: 10.1287/mnsc.42.3.415 $<$ http://dx.doi.org/10.1287/mnsc.42.3.415>

Ishikawa, K. (1985). What is Total Quality Control? The Japanese way. London: Prentice-Hall. 
Karani, S. R. \& Bichanga, W. O.

ISO 8402. (1994). Quality management and quality assurance: Vocabulary. Geneve, Switzerland: International Organization for Standardization.

Juran, J. M. (1994). The upcoming century of quality. Quality Progress, 27(8), 29-37.

Kenya Bureau of Standards. (2008). Implementation of ISO 9000 standards handbook. Nairobi, Kenya: Training and Advisory Services, KEBS.

Kenya Wildlife Service. (2008). Kenya wildlife service strategic plan (2008-2012). Nairobi, Kenya: Kenya Wildlife Service.

Lagrosen, S. (2002). Quality management in Europe: A cultural perspective. The TQM Magazine, 14(5), 275-283. doi: 10.1108/09544780210439707 <http://dx.doi.org/10.1108/09544780210439707>

Longenecker, C. O., \& Scazzero, J. A. (1993). Total Quality Management from theory to practice: A case study. International Journal of Quality \& Reliability Management, 10(5), 24-31. doi: 10.1108/02656719310040114 <http://dx.doi.org/10.1108/02656719310040114>

Mann, R. S. (1992). The development of a framework to assist in the implementation of TQM. Unpublished PhD dissertation. Department of Industrial Studies, University of Liverpool.

Motwani, J. G., Mahmoun, E., \& Rice, G. (1994). Quality practices of Indian organizations: An empirical analysis. International Journal of Quality \& Reliability Management, 11(1), 38-52. doi: 10.1108/02656719410049493 <http://dx.doi.org/10.1108/02656719410049493>

Mugenda, O. L., \& Mugenda, A. G. (1999). Research methods: Qualitative and quantitative approaches. Nairobi: African Centre for Technology Studies (ACTS) press.

Ngware, M. W. (2006). Total Quality Management in secondary schools in Kenya. Quality Assurance in Education, 14(4), 339-362. doi: 10.1108/09684880610703947 <http://dx.doi.org/10.1108/09684880610703947>

Nunnally, J. C. (1970). Introduction to psychological measurement. New York: McGraw-Hill.

Philips, Q. (1995). Philips quality - Let's make things better. Eindhoven, The Netherlands: Corporate Quality Bureau, Philips Electronics.

Rategan, C. (1992). Total Quality Management. Journal of Property Management, 57, 32-34.

Sangeeta, S., \& Banwe, D. K. (2004). Conceptualizing total quality management in higher education. The TQM Magazine, 16(2), 145-159. doi: 10.1108/09544780410523044 $<$ http://dx.doi.org/10.1108/09544780410523044>

Tornow, W. W., \& Wiley, J. W. (1991). Service quality and management practices: A look at employee attitudes, customer satisfaction, and bottom-line consequences. Human Resource Planning, 14, 105-115.

Turney, P., \& Anderson, B. (1989). Accounting for continuous improvement. Sloan Management Review, 30(2), 37-47.

Ugboro, O., \& Obeng, K. (2000). Top management leadership, employee empowerment, job satisfaction and customer satisfaction in TQM organization: An empirical study. Journal of Quality Management, 5, 247-272. doi: 10.1016/S1084-8568(01)00023-2 <http://dx.doi.org/10.1016/S1084-8568(01)00023-2>

Wiklund, H., \& Edvardsson, B. (2003). Innovation and TQM in Swedish higher education institutions possibilities and pittfalls. The TQM Magazine, 15(2), 99-107. doi: 10.1108/09544780310461116 $<$ http://dx.doi.org/10.1108/09544780310461116>

Womack, J. P., \& Roos, D. (1990). The machine that changed the world: Massachusetts Institute of Technology. New York: Rawson Associates.

Zhang, Z. H. (2000). Developing a model of quality management methods and evaluating their effects on business performance. Total Quality Management Journal, 11(1), 129-137. doi: 10.1080/0954412007071 <http://dx.doi.org/10.1080/0954412007071> 